\title{
EFEKTIVITAS KOMUNIKASI KEPALA DESA DALAM MELESTARIKAN TRADISI GOTONG ROYONG DI DESA TABA PASEMAH KABUPATEN BENGKULU TENGAH
}

\author{
Oleh: \\ Evsa Wulan Suri ${ }^{1}$
}

\begin{abstract}
ABSTRAKSI
Gotong royong adalah ciri dari kehidupan bangsa Indonesia yang berlaku secara turuntemurun, sehingga membentuk perilaku sosial yang nyata kemudian membentuk tata nilai kehidupan sosial. Gotong royong adalah warisan budaya yang patut dilestarikan dan menjadi pondasi awal dalam membangun kemandirian desa demi tujuan pembangunan pemerintahan yang optimal. Namun derasnya arus globalisasi mempengaruhi aktualisasi gotong royong menjadi sesuatu yang langka. Penelitian ini dilakukan dengan pendekatan kualitatif, yaitu wawancara mendalam, observasi dan dokumentasi. Informan ini terdiri dari informan kunci yaitu (BPD). hasil penelitian dan pembahasan maka disimpulkan yaitu komunikasi yang dilakukan Kepala Desa Taba Pasemah terbukti sudah cukup efektif dan terjalin baik antara kepala desa dan masyarakat desa sehingga terdapat perubahan perilaku dan sikap bagi masyarakat yang apatis menjadi lebih aktif berperan dalam kegiatan gotong royong. Kepala Desa Taba Pasemah melakukan komunikasi baik secara personal maupun kelompok dan baik tatap muka maupun melalui media elektronik dan mendia sosial internet. Kepala Desa membagi kelompok kegiatan gotong royong seperti kelompok kematian, kelompok yasinan, kelompok acara syukuran, kelompok Sarapal Anam, dan sebagainya. Kepala Desa tetap mengintruksikan warga lain untuk selalu membantu apapun kegiatan yang butuh ditolong bagi warga yang apatis sebagai wujud bentuk komunikasi non verbal yang ampuh membuat warga yang apatis merasa malu dan kedepannya menjadi aktif dalam kegiatan gotong royong.
\end{abstract}

Kata Kunci : efektifitas komunikasi, gotong royong, Bengkulu Tengah

\footnotetext{
${ }^{1}$ Dosen Tetap Prodi Ilmu Administrasi Negara Fisip Unihaz Bengkulu
} 


\section{A. Pendahuluan}

Gotong royong merupakan salah satu ciri khas bangsa Indonesia sebagaimana tertuang dalam Pancasila yaitu sila ke- 3 "Persatuan Indonesia". Perilaku gotong royong telah lama dimiliki Bangsa Indonesia sejak dahulu kala. Gotong royong merupakan keperibadian bangsa dan merupakan budaya yang telah berakar kuat dalam kehidupan.

Gotong royong adalah ciri dari kehidupan bangsa Indonesia yang berlaku secara turun-temurun, sehingga membentuk perilaku sosial yang nyata kemudian membentuk tata nilai kehidupan sosial. Tata nilai yang terbangun di masyarakat menyebabkan gotong-royong selalu terbina dalam kehidupan masyarakat sebagai suatu warisan budaya yang patut dilestarikan.

Keberhasilan suatu pemerintahan daerah tidak luput dari munculnya jiwa nasionalisme dan rasa gotong-royong. Keduanya merupakan kunci utama pembangunan dan sumber daya manusia. Sulit mencapai tujuan tanpa gotong-royong dan kebersamaan. Pasalnya, dalam gotongroyong muncul kepedulian dan kepekaan sosial yang tentunya sangat terkait erat dalam kegiatan pembangunan, kemasyarakatan, dan tentunya pemerintahan.

Dalam pelaksanaan kepemerintahan pun harus selalu relevan, dimana partisipasi masyarakat apapun bentuknya akan selalu memberi kontribusi positif bagi pencapaian tujuan pembangunan kemajuan pemerintahan yang optimal. Kalau pun ada sebuah prestasi yang diterima pemerintah. Tentu ini tidak terlepas dari partisipasi seluruh pihak dalam pencapaian prestasi tersebut.

Berdasarkan Ketentuan Pasal 26 Undang-Undang Nomor 6 Tahun 2014 Tentang Desa, Kepala Desa bertugas menyelenggarakan Pemerintahan Desa, melaksanakan Pembangunan Desa, pembinaan kemasyarakatan Desa, dan pemberdayaan masyarakat Desa.

Sesuai dengan Undang-undang tersebut dapat diinterprestasikan bahwa Kepala Desa juga berkewajiban untuk berperan aktif untuk melakukan pembinaan masyarakat salah satunya agar budaya gotong royong tetap terpelihara dalam rangka mendukung pembangunan desa secara mandiri. Pembinaan masyarakat dapat dilakukan tentunya melalui komunikasi yang efektif kepada masyarakat.

Mengingat pentingnya upaya pelestarian dan pemeliharaan budaya gotong royong, maka penulis bermaksud untuk melakukan penelitian dan mengukur sejauhmana efektifitas komunikasi Kepala Desa dalam memelihara tradisi gotong royong di Desa Taba Pasemah Kecamatan Talang Empat Kabupaten Bengkulu Tengah.

\section{B. Metode Penelitian}

Penelitian ini adalah penelitian deskriptif kualitatif, yang bertujuan memberikan gambaran secara jelas suatu fenomena atau kenyataan sosial yang berkenaan dengan masalah yang diteliti (Prastowo, 2010:31) khususnya tentang efektivitas komunikasi kepala desa dalam melestarikan tradisi gotong royong di Desa Taba Pasemah Kabupaten Bengkulu Tengah. Informan yang dilibatkan merupakan orang yang dapat memberikan informasi tentang situasi dan kondisi latar belakang penelitian (Koentjaraningrat, 1991:69).

Adapun rincian informan yang digunakan dalam penelititan ini adalah sebagai berikut:

1. Kepala Desa 1 orang

2. Sekretaris Desa dan Aparat

3. Tokoh dan warga masyarakat

Dalam penelitian ini data-data yang diperoleh berdasarkan sumbernya dapat digolongkan menjadi dua bagian yaitu data primer dan data sekunder. Data primer merupakan data yang diperoleh dari informan dengan cara wawancara maupun pengamatan secara langsung, sedangkan data sekunder merupakan data yang bersumber dari dokumen-dokumen arsip tertentu yang berhubungan dengan penelitian (Koentjaraningrat, 1991:37). Adapun beberapa teknik pengumpulan data dalam penelitian ini, yaitu: a. Observasi, wawancara, observasi, dokumen-dokumen, undang-undang, dan media informasi lainnya yang berkaitan dengan hal-ihwal budaya gotong royong di Desa Taba Pasemah Kabupaten Bengkulu Tengah. Data yang telah dikumpulkan akan dianalisa secara kualitatif yakni data yang diperoleh akan dianalisis dalam bentuk kata-kata lisan maupun tulisan. Teknik ini bertujuan untuk memperoleh gambaran yang umum dan menyeluruh dari obyek penelitian. Serta hasil-hasil penelitian baik dari hasil studi lapang maupun studi literatur untuk kemudian memperjelas gambaran hasil penelitian (Sugiyono, 2008:88). Prosedur dan analisis data dilakukan dengan berbagai 
tahapan yang meliputi: data reduction (reduksi data), data display (penyajian data). Data yang ditelah direduksi kemudian disajikan dalam bentuk uraian naratif, sehingga data tersebut benar-benar dipahami, dan conclution drawing (penarikan kesimpulan)

Penelitian ini memfokuskan pada efektivitas komunikasi kepala desa dalam melestarikan tradisi gotong royong di desa Taba Pasemah Kabupaten Bengkulu Tengah.

\section{Hasil Penelitian dan Pembahasan}

1. Efektivitas Komunikasi Kepala Desa Dalam Melestarikan Tradisi Gotong Royong Di Desa Taba Pasemah Kabupaten Bengkulu Tengah

Kegiatan gotong-royong yang dilakukan di Desa Taba Pasemah antara lain seperti apa yang dikemukakan oleh kontjaningrat yaitu dalam hal kematian, sakit, atau kecelakaan, pesta-pesta, khitanan, seperti memperbaiki jalan, jembatan, membersihkan parit atau siring dan sebagainya. Semua jenis kegiatan gotong-royong yang di sebutkan di atas tidak akan dapat terlaksana jika tidak ada yang memimpin, memberikan informasi, mempengaruhi, mengajak dan menggerakkan masyarakat untuk bergotong royong, saling tolong menolong atau bekerja sama mengerjakan sesuatu pekerjaan yang membutuhkan tenaga orang banyak.

\section{a. Penyampaian Pesan}

Pesan yang disampaikan oleh kepala desa umumnya adalah pesan yang bersifat persuasif dan informatif saja, yaitu pesan yang dirancang untuk membujuk, mengajak, mendorong masyarakat untuk tetap bersemangat melakukan kegiatan gotong-royong yang ada di desa Taba Pasemah. Sementara khusus bagi tipikal warga yang acuh, kades Taba Pasemah memiliki cara komunikasi non verbal atau sikap yang bersifat "menyindir" yakni dengan tetap turut membersihkan parit atau halaman depan rumah warga yang apatis sekalipun dengan tujuan agar warga yang apatis bisa menyadari sikapnya yang dalam hal ini bentuk penyampaian secara primer. Penyampaian pesan dengan cara primer adalah proses penyampaian pikiran dan atau perasaan sesorang kepada orang lain dengan menggunakan simbol sebagai media. Lambang media primer adalah bahasa, isyarat, gambar, warna, dan lain sebagainya. Yang secara langsung mampu menerjemahkan pikiran dan atau perasaan komunikator kepada komunikan. Proses penyampaian pesan secara primer yang dilakukan oleh Kepala Desa beserta perangkat desa lainnya dengan menggunakan komunikasi kelompok.

\section{b. Media Komunikasi}

Media penyampaian informasi dari kepala desa kepada masyarakat desa umumnya komunikasi langsung tatap muka baik dalam kegiatan perencanaan, pelaksanaan dan evaluasi. Kepala Desa sebagai komunikator mengenal khalayak/ komunikannya seperti pendidikan, mata pencaharian, suku, bahasa, keyakinan/ kepercayaan, adat istiadat, dan lain-lain. Selain itu Kepala desa Taba Pasemah juga menggunakan sarana media sosial untuk menghimbau warga, menginformasikan kepada warga yang bersifat persuasif dan mendorong semangat warga untuk selalu peduli dengan kegiatan gotong royong.

Menurut Fajar Marhaeni dalam buku Ilmu Komunikasi Teori dan Praktik (2009:108) "mengatakan dalam proses komunikasi, baik komunikator maupun khalayak mempunyai kepentingan yang sama. Tanpa persamaan kepentingan komunikasi tidak mungkin berlangsung. Justru itu, untuk berlangsungnya komunikasi dan kemudian tercapainya hasil yang positif, maka komunikator harus menciptakan persamaan kepentingan dengan khalayak terutama dalam pesan, metoda dan media". Persamaan kepentingan antara komunikator dan komunikan dalam hal ini adalah komunikator berusaha menyamakan pandangan masyarakat Taba Pasemah tentang pentingnya persatuan dalam masyarakat khususnya dalam kegiatan gotong-royong, saling membantu, menghargai satu dengan yang lainnya. Dengan menggunakan media bahasa yang dapat dimengerti oleh masyarakat dalam hal ini menggunakan komunikasi kelompok. Sehingga pesan yang disampaikan dapat dimengerti dan diterima oleh khalayak dalam hal ini adalah masyarakat desa Taba Pasemah.

Sebagaimana yang diungkapkan oleh aparat desa bahwa walaupun tidak diadakan rapat secara formal namun koordinasi antar aparat, kepala lingkungan, lembaga kemasyarakatan, dan warga selalu terjalin. Karena tradisi gotong royong memang sudah terjaga sejak lama. Namun jika dibandingkan dengan sebagai pemerintah yang melaksanakan fungsi pemerintahan sebagai pengatur (regulasi) masyarakat, maka sudah selayaknya apabila seseorang Kepala desa mengetahui kondisi 
atau keadaan penduduknya yang sebenarnya. Sebab dengan mengetahui kondisi masyarakat yang sebenarnya maka dapat diambil langkah-langkah yang tepat dalam mengambil keputusan dan tindakan. Sebab jika pemimpin tidak mengetahui kondisi masyarakat maka akan menjadi suatu kesalah pahaman yang tidak dapat diterima oleh masyarakat. Hal ini senada dengan hasil wawancara pada bagian sebelumnya yaitu: kondisi penduduk Desa Taba Pasemah yang cukup beragam ini harus diperhatikan oleh Kepala Desa dalam menjalankan tugasnya.

Dalam komunikasi kerap juga terjadi noise atau gangguan sehingga feed back yang diharapkan tidak efektif sesuai harapan. Hal ini terjadi dikondisi komunikan sendiri yakni warga Taba Pasemah yang memiliki status pendidikan rendah sehingga sulit untuk memberi kontribusi pemikiran atau ide, dan disini kepala desa harus mampu menganalisis situasi komunikasi agar tidak terjadi kesalahan informasi dan sikap.

Warga desa Taba Pasemah tidak lepas dari konflik sehingga menghambat partisipasi individu dalam gotong royong. Namun interaksi social selalu diusahakan agar supaya kesatuan social (social unity) tidak terganggu, konflik atau pertentangan social sedapat mungkin dihindarkan jangan sampai terjadi. Bahkan kalau terjadi konflik diusahakan supaya konflik tersebut tidak terbuka dihadapan umum. Bila terjadi pertentangan diusahakan untuk dirukunkan karena memang prinsip kerukunan inilah yang menjiwai hubungan social pada masyarakat pedesaan karena masyarakat ini sangat mendambakan tercapainya keserasian dalam kehidupan masyarakat. Apabila masyarakatnya rukun maka kegiatan gotong royong dalam segala hal tetap terjaga, lestari dan terpelihara.

\section{Kesimpulan dan Saran}

\section{Kesimpulan}

Dari hasil penelitian yang telah peneliti lakukan, penyajian data dan pembahasan maka dapat dikemukakan beberapa kesimpulan sebagai berikut :

Budaya gotong-royong masih dilestarikan di desa Taba Pasemah meskipun zaman sudah berubah, kegiatan-kegiatan gotong-royong yang masih dilakukanseperti membuat kelompok-kelompok kegiatan gotong royong sesuai dengan tugasnya seperti kelompok kematian, kelompok yasinan, kelompok sarapa anam, kelompok acara dan syukuran sampai kelompok keamanan. Kepala desa sebagai komunikator mampu merangkul warga baik mendengarkan aspirasi, member solusi, persuasi, dan mencari cara untuk mengembalikan semangat gotong royong bagi warga yang apatis terhadap kegiatan gotong royong bentuk komunikasi yang dilakukan oleh kepala desa sudah berjalan dengan baik, yaitu melalui komunikasi kelompok dengan mempersiapkan elemenelemen komunikasi yang ada dengan sebaikbaiknya diantaranya:

a. Source/ Komunikator : Kepala Desa

b. Message/Pesan: Pesan yang di sampaikan kepada masyarakat adalah pesan yang bersifat informatif dan persuasif.

c. Channel/ Media : Media yang di gunakan adalah media primer (komunikasi kelompok) komunikasi kelompok atau komunikasi primer sebagai media yang digunakan dalam menyampaikan pesan yang berhubungan dengan kegiatan gotongroyong karena itu adalah media yang tepat untuk digunakan di desa Taba Pasemah. Selain itu media yang digunakan melalui media social seperti facebook.

d. Receiverl Penerima : Warga Taba Pasemah yang harus dikenali secara utuh karakter dan budaya karena bersifat saling mempengaruhi komunikator kekomunikan begitu juga sebaliknya.

\section{Saran}

Berdasarkan kesimpulan di atas, maka disarankan agar Kepala Desa selalu memberikan pengaruh yang kuat mengenai efektivitas gotong royong kepada masyarakat yang memilik sifat apatis dengan pendekatan yang lebih inten supaya tradisi gotong royong tidak luntur dengan kemajuan zaman seperti saat ini.

\section{DAFTAR PUSTAKA}

Sumber dari Buku :

Abdulrahman M. A, Demi. Dasar-dasar Public Relation. 1975. Bandung : Alumni.

Bungin, burham. Sosiologi Komunikasi. 2006. Jakarta : Fajar Interpratama.

Davis, Suhartin Citrobroto. 1978. Prinsipprinsip dan Teknik Berkomunikasi. jakarta : Batara Karya Aksara.

Koentjaraningrat. 1984. Kebudayaan Pembangunan dan Mentalitet. Jakarta : Gramedia Pustaka Utama. 
MIMBAR

JURNAL PENELITIAN SOSIAL DAN POLITIK

Koentjaraningrat. 1991. Metode penelitian Kualititatif. Jakarta : Gramedia Pustaka Utama.

Rakhmat, Jalaludin. Psikologi Komunikasi. 2003. Jakarta : Rosdakarya.

Widjaja, AW. 2000. Ilmu Komunikasi Pengantar Studi.Jakarta: PT. Rineka Cipta

\section{Website}

https://www.kompasiana.com/swaramahardhika/memahami-makna-gotongroyong_54f8470fa333112a608b51c7, diakses tanggal 3 Desember 2017). 